\title{
Temperature - Potential Evapotranspiration Relationship in Iraq Using Thornthwaite Method
}

\author{
Hussein Ilaibi Zamil Al-Sudani* \\ Petroleum Technology Department. University of Technology. Baghdad. Iraq. \\ dr.hussein_alsudani@yahoo.com 150098@uotechnology.edu.iq
}

\begin{tabular}{|l|l|l|}
\hline Submission date:- 9/12/2018 & Acceptance date:- 8/1/2019 & Publication date:- 10/1/2019 \\
\hline
\end{tabular}

\begin{abstract}
One of the most important outcomes in the water balance equation for any natural area or water body is Evapotranspiration and it is also a crucial component of the hydrologic cycle. The relationship of temperature - evapotranspiration was obtained using the Thornthwaite method in Iraq by dividing the area into (7) sectors according to geographic latitude. Each sector has multi meteorological stations where (32) stations were used with different periods of records. A mathematical relationship was obtained between mean temperature and corrected potential evapotranspiration (PEc) with (97.45) to (99.84) coefficient of determination. Mean temperature has a symmetrical decreasing pattern from south-east towards north-west of Iraq affected by Mediterranean Sea climate conditions, while correcting potential evapotranspiration $(\mathrm{PEc})$ has the opposite direction of increasing values due to a direct relationship with temperature.
\end{abstract}

Keywords: Potential Evapotranspiration, Thornthwaite Method, Iraq.

\section{Introduction}

Water is a vital component to the development of any area. The demand of water increased recently because of the growing population, where water for agriculture and other demands becomes limited [1]. Climate and hydrological conditions in any hydrological basin are multi-combined reflection of natural factors of morphology and soil nature, as well as the changing in climate factors that affect directly on hydrological cycle [2]. The water balance equation for any natural area or water body indicates the relative values of inflow, outflow and change in water storage in the area or water body [3]. One of the most important outcomes in water balance equation for any natural area or water body is Evapotranspiration and it is also a crucial component of hydrologic cycle [4]. It can be defined as the combination of two separate processes through which, water is lost from the soil surface via evaporation process and from the crop by transpiration [5]. Evapotranspiration consider a main requirement in planning and designing any irrigation project in arid and semiarid regions [6]. Thornthwaite method is one of the significant methods used to estimate the potential Evapotranspiration (PE) that is based on the monthly average temperature. This method can be appropriately used in arid and semi-arid regions [7]. Thornthwaite method is widely used for estimating potential evapotranspiration was derived by (Thornthwaite,1948) [8], who correlated mean monthly temperature with evapotranspiration as determined from water balance for valleys where sufficient moisture water was available to maintain active transpiration. Potential Evapotranspiration can be calculated by applying following formula [9]:

$$
\begin{aligned}
& P E=16\left[\frac{10 t n}{J}\right]^{a} \\
& J=\sum_{1}^{12} j
\end{aligned}
$$




$$
\begin{aligned}
& j=\left[\frac{t n}{5}\right] \\
& a=0.016 J+0.5
\end{aligned}
$$

PE: potential evapotranspiration, J: Heat Index, j: Coefficient monthly temperature $\left({ }^{\circ} \mathrm{C}\right)$, a: Constant, tn: Average monthly temperature $\left({ }^{\circ} \mathrm{C}\right)$.

Prediction of monthly evapotranspiration can be obtained depending on observed monthly average temperatures at a meteorological station in each year, despite the fact that this formula is shown by many researches to underestimate (PE), it has been accepted widely around the globe [10]. Thus relationship can be estimated between those two parameters in order to facilitate calculation of water balance of lakes, river basins, and ground-water basins as well as reducing cost and time.

The relationship of temperature - evapotranspiration obtained by Thornthwaite method in Iraq is the main objective of this research. Temperature as a key factor controlling on monthly evapotranspiration can be obtained by dividing Iraqi area into (7) sectors according to geographic latitude. Each sector has multi meteorological stations where (32) stations were used all over Iraq.

Iraq is sited between latitude $\left(29.00^{\circ}-37.22^{\circ} \mathrm{N}\right)$ and longitude $\left(38.45^{\circ}-48.30^{\circ} \mathrm{E}\right)$, while climate of Iraq is generally as continental and subtropical semi-arid type whereas the mountainous regions are classified a Mediterranean climate. It is characterized by a very hot summer and a short cold winter and also by the breadth of the daily and annual temperature because of the lack of large water bodies that reduce the coldness of winter and summer heat [11].

Many pervious studies were used Thornthwaite method to calculate evapotranspiration in specific region of Iraq in order to estimate water balance, while one research has been found using geographic information system to estimate the Evapotranspiration in Iraq according to Thornthwaite formula. This research used (11) meteorological stations to estimate global warming influence on the annual mean value of temperature and yet on the annual mean value of the evapotranspiration for more than three decades in Iraq [12].

\section{Material:}

The materials used in this research were:

1- Annual and monthly temperature records for (32) meteorological stations with their geographic coordinates from date of station operation until 2015 [13].

2- Thornthwaite formula [8].

3- Grapher and Surfer programs demonstrating graphs and contour maps.

\section{Methodology:}

In this research annual and monthly air temperatures of (32) meteorological stations were used to calculate potential evapotranspiration (PE) using Thornthwaite method. These stations were divided according to Iraqi geographic latitude from (30-31) in the south to (36-37) in the north of Iraq, Table (1) Fig (1). Calculated potential evapotranspiration (PE) was compared with temperature in all station located in the same sector. Statistical approach was used to identify the types of equations for each group of stations using Grapher program. Finally Surfer program was used to demonstrate contour map of heat and corrected potential evapotranspiration (PEc) in Iraq. 
Journal of University of Babylon for Engineering Sciences, Vol. (27), No. (1): 2019.

Table 1: Geographical position of meteorological stations in Iraq

\begin{tabular}{||c|c|c|c|c|c|c|c||}
\hline \multicolumn{2}{|l}{ Location of stations } & \multirow{2}{*}{$\begin{array}{c}\text { Name of } \\
\text { Long. }\end{array}$} & Lat. & Station & \multicolumn{2}{|c|}{ Location of stations } & Name of \\
Station & No. & Long. & Lat. & Station \\
Station & No. \\
\hline 444300 & 323300 & Ainaltamer & 1 & 433600 & 354500 & Makhmoor & 17 \\
\hline 471000 & 315100 & Amarah & 2 & 430900 & 361900 & Mosul & 18 \\
\hline 415700 & 342800 & Anah & 3 & 441900 & 315900 & Najaf & 19 \\
\hline 450400 & 325500 & Azizyah & 4 & 421500 & 320200 & Nukhaib & 20 \\
\hline 414400 & 360200 & Baaj & 5 & 461400 & 310500 & Nasiriyah & 21 \\
\hline 455700 & 330600 & Badra & 6 & 410100 & 342300 & Qaim & 22 \\
\hline 441400 & 331400 & Baghdad & 7 & 420600 & 364800 & Rabiah & 23 \\
\hline 432900 & 345600 & Baiji & 8 & 430900 & 332700 & Ramadi & 24 \\
\hline 474700 & 303400 & Basrah & 9 & 401700 & 330200 & Rutba & 25 \\
\hline 445900 & 315900 & Diwaniyah & 10 & 435300 & 341100 & Samaraa & 26 \\
\hline 460300 & 321000 & Hai & 11 & 451600 & 311800 & Samawah & 27 \\
\hline 442700 & 322700 & Hilla & 12 & 415000 & 361900 & Sinjar & 28 \\
\hline 440100 & 323700 & Karbalaa & 13 & 422900 & 362200 & Tel-Afer & 29 \\
\hline 443200 & 335000 & Khalis & 14 & 434200 & 343400 & Tikrit & 30 \\
\hline 452600 & 341800 & Khanaqin & 15 & 443900 & 345300 & Tuz & 31 \\
\hline 442400 & 352800 & Kirkuk & 16 & 360900 & 440000 & Erbeel & 32 \\
\hline
\end{tabular}

\section{Results and discussion:}

Table 2 shows the (7) groups of meteorological stations located in each sector according to Iraqi latitude. Using Thornthwaite formula [8] showed in equation $(1,2,3,4)$ previously, the annual corrected potential evapotranspiration (PEc) was calculated after using correction factor of sunlight duration and number of day light according to latitude, Table 3. Table 4 shows the mean annual temperature and summation of annual (PEc).

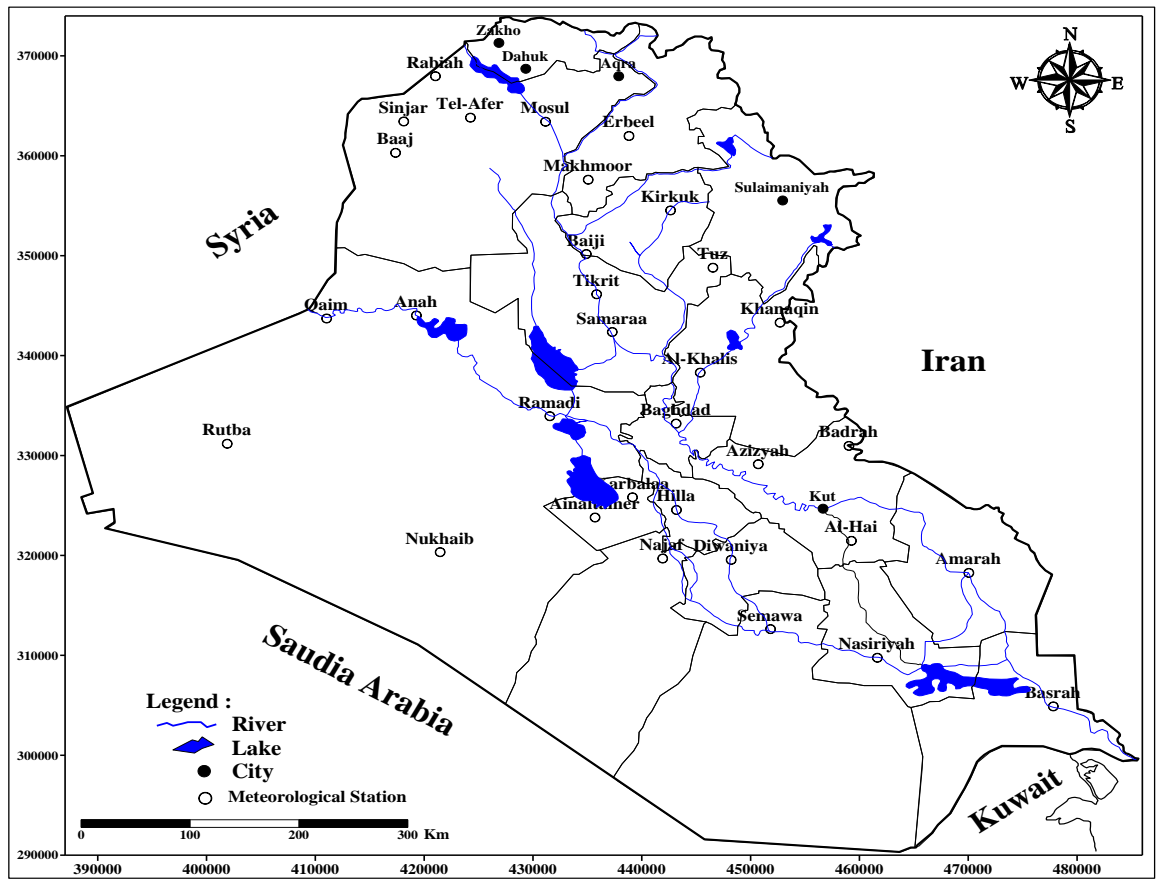

Fig. 1: Distribution map of Meteorological stations in Iraq. 
Table 2: Groups of meteorological stations located in each sector

\begin{tabular}{||c|c|c|c|}
\hline $\begin{array}{c}\text { Sector } \\
\text { No. }\end{array}$ & $\begin{array}{c}\text { Sum of } \\
\text { Station }\end{array}$ & $\begin{array}{c}\text { Geographic } \\
\text { latitude }\end{array}$ & Stations \\
\hline $\mathbf{1}$ & 2 & $30-31$ & Basrah and Nasriyah \\
\hline $\mathbf{2}$ & 4 & $31-32$ & Amarah, Diwaniyah, Najaf and Samawah \\
\hline $\mathbf{3}$ & 6 & $32-33$ & Aintamer Aziziyah, Hai, Hella, Karbala and Nukhaib \\
\hline $\mathbf{4}$ & 5 & $33-34$ & Badra, Baghdad, Khalis, Ramadi, Rutba \\
\hline $\mathbf{5}$ & 6 & $34-35$ & Anah, Khanaqin, Qaim, Samaraa, Tikrit and Tuz \\
\hline $\mathbf{6}$ & 3 & $35-36$ & Baiji, Kirkuk and Makhmoor \\
\hline $\mathbf{7}$ & 6 & $36-37$ & Erbeel, Baaj, Mosul, Rabiah, Sinjar and Tel-Afar \\
\hline
\end{tabular}

Table 3: Constant K in Thornthwaite method* [8]

\begin{tabular}{|c|c|c|c|c|c|c|c|c|c|c|c|c|}
\hline Latitude & Jan. & Feb. & Mar. & Apr. & May & June & July & Aug. & Sep. & Oct. & Nov. & Dec. \\
\hline $60^{\circ} \mathbf{N}$ & 0.54 & 0.67 & 0.97 & 1.19 & 33 & 56 & .55 & 1.33 & 1.07 & .84 & .58 & .48 \\
\hline $\mathbf{5 0}^{\circ} \mathbf{N}$ & 0.71 & 0.84 & 0.98 & 1.14 & 1.28 & 1.36 & 1.33 & 1.21 & 1.06 & 0.9 & 0.76 & 0.68 \\
\hline $40{ }^{\circ} \mathbf{N}$ & 0.8 & 0.89 & 0.99 & 1.1 & 1.2 & 1.25 & 1.23 & 1.15 & 1.04 & 0.93 & 0.83 & 0.78 \\
\hline $30^{\circ} \mathbf{N}$ & 87 & 0.93 & 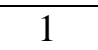 & 1.7 & .14 & .17 & 1.16 & 1.11 & 1.03 & 0.96 & .89 & 0.85 \\
\hline $20^{\circ} \mathbf{N}$ & .92 & 0.96 & 1 & 1.05 & 1.09 & 1.11 & 1.1 & 1.07 & 1.02 & 0.98 & 0.93 & 0.91 \\
\hline $10^{\circ} \mathrm{N}$ & 0.97 & 0.98 & 1 & 1.03 & 1.05 & 1.06 & 1.05 & 1.04 & 1.02 & 0.99 & 0.97 & 0.96 \\
\hline $00^{\circ} \mathbf{N}$ & 1 & 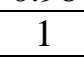 & 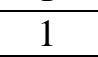 & 1 & 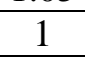 & 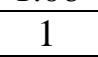 & 1 & 1 & 1 & 1 & 1 & 1 \\
\hline $10^{\circ} \mathrm{S}$ & 1.05 & 1.04 & 1.02 & 0.99 & 0.97 & 0.96 & 0.97 & 0.98 & 1 & 1.03 & 1.05 & 1.06 \\
\hline $20^{\circ} \mathrm{S}$ & 1.1 & 1.07 & 1.02 & 0.98 & 0.93 & 0.91 & 0.92 & 0.96 & 1 & 1.05 & 1.09 & 1.11 \\
\hline $30^{\circ} \mathrm{S}$ & 1.16 & 1.11 & 1.03 & 0.94 & 0.89 & 0.85 & 0.87 & 0.93 & 1 & 1.07 & 1.14 & 1.17 \\
\hline $4^{\circ} \mathrm{S}$ & 1.23 & 1.15 & 1.04 & 0.93 & 0.83 & 0.78 & 0.8 & 0.98 & 0.99 & 1.1 & 1.2 & 1.25 \\
\hline $50^{\circ} \mathrm{S}$ & 1.33 & 1.19 & 1.05 & 0.98 & 0.75 & 0.68 & 0.7 & 0.82 & 0.97 & 1.13 & 1.27 & 1.36 \\
\hline
\end{tabular}

$\mathrm{K}$ : is a constant to correct $\mathrm{PE}$ for latitude other than $0^{\circ}$.

Table 4: Mean annual temperatures and corrected evapotranspiration (PEc) calculated in each meteorological station in Iraq

\begin{tabular}{||c|c|c|c|c|c|c|c|}
\hline $\begin{array}{c}\text { St. } \\
\text { No. }\end{array}$ & $\begin{array}{c}\text { Annual } \\
\text { Mean } \\
\text { Tem. (C) }\end{array}$ & $\begin{array}{c}\text { Sum of } \\
\text { corrected } \\
\text { (PEc) }(\mathbf{m m})\end{array}$ & $\begin{array}{c}\text { Duration } \\
\text { (years) }\end{array}$ & $\begin{array}{c}\text { St. } \\
\text { No. }\end{array}$ & $\begin{array}{c}\text { Annual } \\
\text { Mean } \\
\text { Tem. (C) }\end{array}$ & $\begin{array}{c}\text { Sum of } \\
\text { corrected } \\
\text { (PEc) (mm) }\end{array}$ & $\begin{array}{c}\text { Duration } \\
\text { (years) }\end{array}$ \\
\hline $\mathbf{1}$ & 22.279 & 1579.066 & 20 & $\mathbf{1 7}$ & 22.677 & 1792.035 & 19 \\
\hline $\mathbf{2}$ & 24.804 & 2318.14 & 35 & $\mathbf{1 8}$ & 20.1093 & 1327.295 & 70 \\
\hline $\mathbf{3}$ & 20.958 & 1388.118 & 38 & $\mathbf{1 9}$ & 24.406 & 2185.641 & 40 \\
\hline $\mathbf{4}$ & 23.968 & 2014.677 & 15 & $\mathbf{2 0}$ & 22.279 & 1579.066 & 20 \\
\hline $\mathbf{5}$ & 20.487 & 1361.543 & 17 & $\mathbf{2 1}$ & 25.092 & 2257.156 & 73 \\
\hline $\mathbf{6}$ & 24.546 & 2330.101 & 15 & $\mathbf{2 2}$ & 20.966 & 1383.538 & 20 \\
\hline $\mathbf{7}$ & 22.694 & 1674.369 & 66 & $\mathbf{2 3}$ & 18.52 & 1122.652 & 31 \\
\hline $\mathbf{8}$ & 22.44 & 1697.278 & 30 & $\mathbf{2 4}$ & 22.073 & 1515.101 & 25 \\
\hline $\mathbf{9}$ & 24.876 & 2132.123 & 67 & $\mathbf{2 5}$ & 19.738 & 1182.171 & 35 \\
\hline $\mathbf{1 0}$ & 24.262 & 2033.104 & 38 & $\mathbf{2 6}$ & 23.136 & 1845.079 & 26 \\
\hline $\mathbf{1 1}$ & 24.435 & 2139.199 & 68 & $\mathbf{2 7}$ & 24.748 & 2242.733 & 38 \\
\hline $\mathbf{1 2}$ & 23.259 & 1773.72 & 25 & $\mathbf{2 8}$ & 20.556 & 1399.499 & 42 \\
\hline $\mathbf{1 3}$ & 24.114 & 2087.377 & 38 & $\mathbf{2 9}$ & 21.043 & 1464.71 & 25 \\
\hline $\mathbf{1 4}$ & 22.016 & 1511.515 & 17 & $\mathbf{3 0}$ & 23.0471 & 1910.049 & 24 \\
\hline $\mathbf{1 5}$ & 22.834 & 1751.833 & 60 & $\mathbf{3 1}$ & 22.794 & 1768.054 & 17 \\
\hline $\mathbf{1 6}$ & 22.195 & 1662.425 & 68 & $\mathbf{3 2}$ & 21.321 & 1488.116 & 40 \\
\hline
\end{tabular}


Depending on Table 4, Figs. 2 and 3 show the mathematical relationship between monthly mean temperature and monthly corrected potential evapotranspiration (PEc) calculated in each group within (7) sectors. Table 5 shows the obtained equation of mathematical relationship between temperature and (PEc) in each sector.

Table 5: Equations obtained between temperature and (PEc) in each sector

\begin{tabular}{||c|c|c|c||}
\hline $\begin{array}{c}\text { Sector } \\
\text { No. }\end{array}$ & Station No. & Equation and alternate equation & R-squared \% \\
\hline $\mathbf{1}$ & 9 and 21 & $\begin{array}{c}\log (\mathrm{PEc})=3.74303 * \log (\mathrm{T})+-7.30851 \\
\mathrm{PEc}=\mathrm{T}^{\wedge}(3.74303) * 0.000669814\end{array}$ & 99.84 \\
\hline $\mathbf{2}$ & $2,10,19$ and 27 & $\begin{array}{c}\log (\mathrm{PEc})=3.62641 * \log (\mathrm{T})+-6.91808 \\
\mathrm{PEc}=\mathrm{T}^{\wedge}(3.62641) * 0.000989726\end{array}$ & 99.81 \\
\hline $\mathbf{3}$ & $\begin{array}{c}1,4,11,12,13 \\
\text { and } 20\end{array}$ & $\begin{array}{c}\log (\mathrm{PEc})=3.28486 * \log (\mathrm{T})+-5.77718 \\
\mathrm{PEc}=\mathrm{T}^{\wedge}(3.28486) * 0.00309742\end{array}$ & 99.15 \\
\hline $\mathbf{4}$ & $6,7,14,24$ & $\begin{array}{c}\log (\mathrm{PEc})=2.97073 * \log (\mathrm{T})+-4.73113 \\
\mathrm{PEc}=\mathrm{T}^{\wedge}(2.97073) * 0.00881649\end{array}$ & 97.45 \\
\hline $\mathbf{5}$ & $\begin{array}{c}3,15,22,26,30 \\
\text { and } 31\end{array}$ & $\begin{array}{c}\log (\mathrm{PEc})=3.02967 * \log (\mathrm{T})+-4.92707 \\
\mathrm{PEc}=\mathrm{T}^{\wedge}(3.02967) * 0.00724772\end{array}$ & 98.96 \\
\hline $\mathbf{6}$ & 8,16 and 17 & $\begin{array}{c}\log (\mathrm{PEc})=3.0942 * \log (\mathrm{T})+-5.14115 \\
\mathrm{PEc}=\mathrm{T}^{\wedge}(3.0942) * 0.00585097\end{array}$ & 99.74 \\
\hline $\mathbf{7}$ & $\begin{array}{c}5,18,23,28,29 \\
\text { and } 32\end{array}$ & $\begin{array}{r}\log (\mathrm{PEc})=2.61248 * \log (\mathrm{T})+-3.54622 \\
\mathrm{PEc}=\mathrm{T}^{\wedge}(2.61248) * 0.0288333\end{array}$ & 98.93 \\
\hline
\end{tabular}

It seems that sector (4) has the lower coefficient of determination (R-squared) among other sectors. This sector located within latitude (33-34) and has (5) meteorological stations distributed on wide range in middle of Iraq from west to east. Four of these stations are closed together (Badra, Khalis, Baghdad and Ramadi) while Rutba station is located almost near the Iraqi - Jordanian border. The recorded mean temperatures in four stations which located in the middle and eastern side of Iraq was ranged (22.016 24.546 C) and potential evapotranspiration was ranged (1511.515 - $2330.101 \mathrm{~mm})$, while mean temperatures in Rutba station was (19.738) and potential evapotranspiration was (1182.171 mm) due to desert climate. This difference affects on potential evapotranspiration calculated in this station compared to other stations in the same sector. 

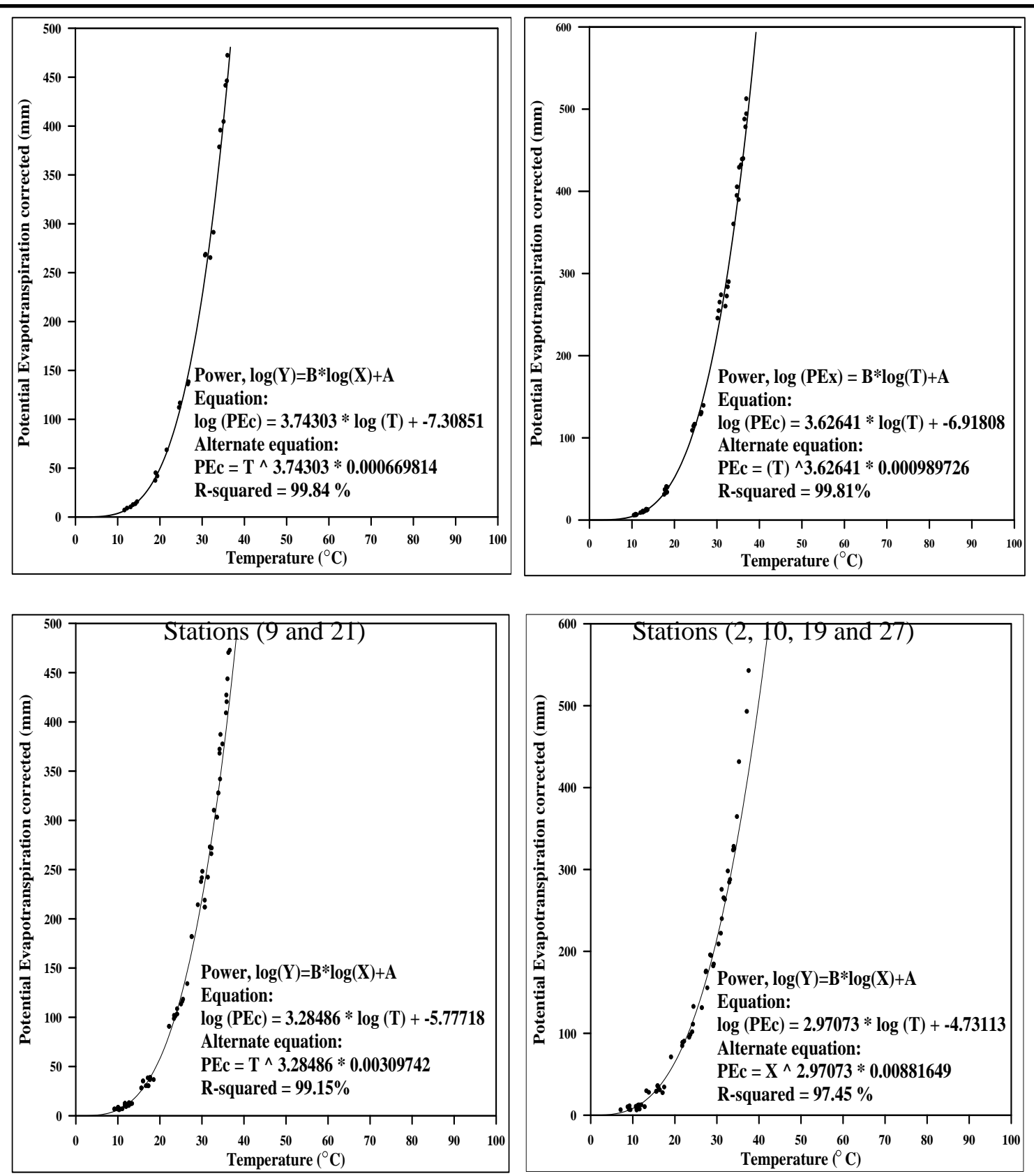

Stations $(1,4,11,12,13$ and 20)

Stations $(6,7,14,24$ and 25)

Fig. 2: Mathematical relationship between temperatures and (PEc). 

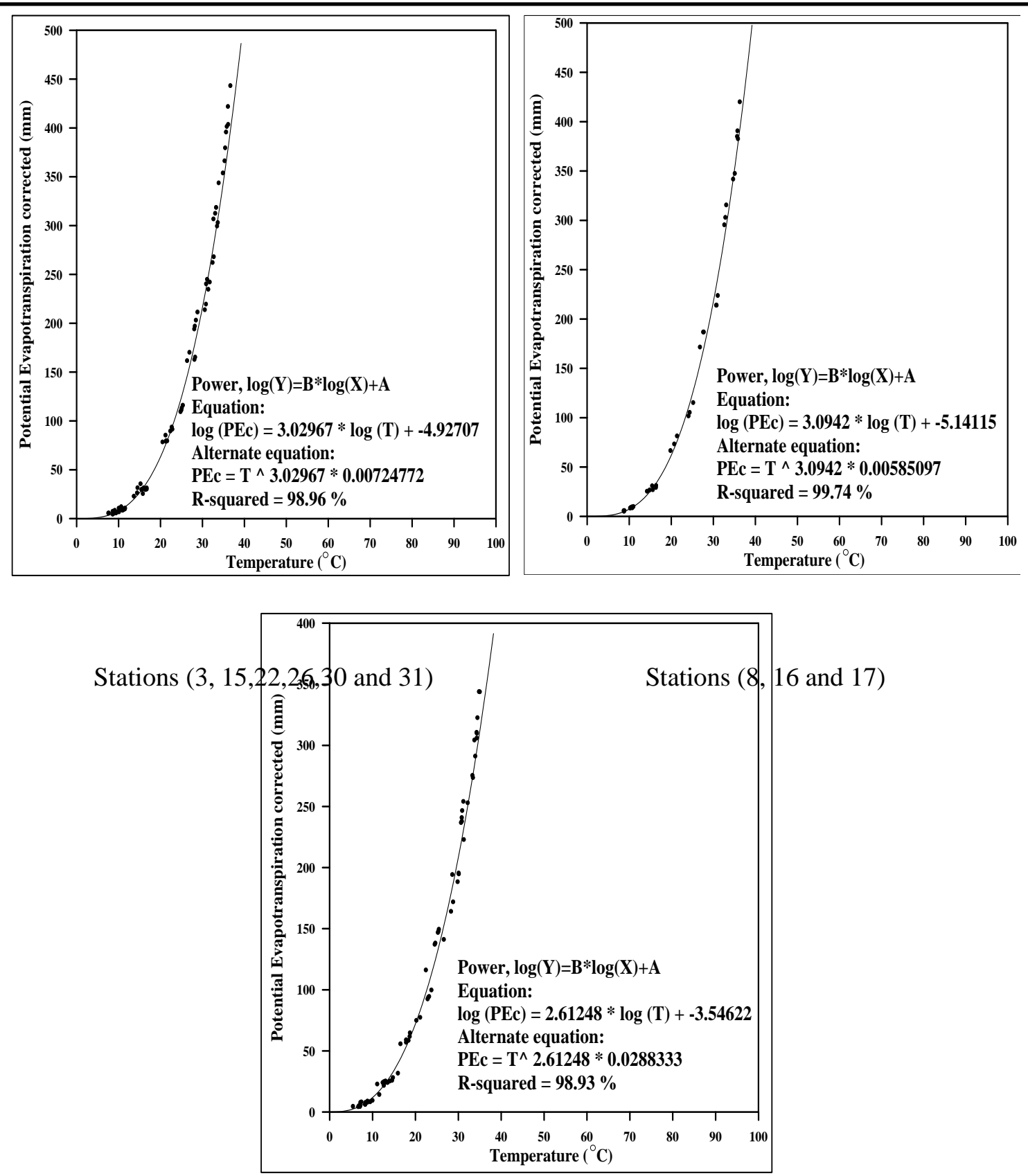

Stations $(5,18,23,28,29$ and 32)

Fig. 3: Mathematical relationship between temperatures and (PEc).

Depending on Table 4, the mean temperature in (32) stations was demonstrated in Fig. 4, while Fig. 5 show the distribution of correcting potential evapotranspiration $(\mathrm{PEc})$ in Iraq. It seems that mean temperature has a symmetrical decreasing pattern from south-east towards north-west due to high relative humidity rates in the north-west part of Iraq because of its geographic location towards Mediterranean Sea and its climate condition which reduce the mean annual and monthly temperatures. On the other hand the 
distribution of correcting potential evapotranspiration (PEc) as shown in Fig. 5 has the opposite direction of increased value of Evapotranspiration due to a direct relationship with temperature.

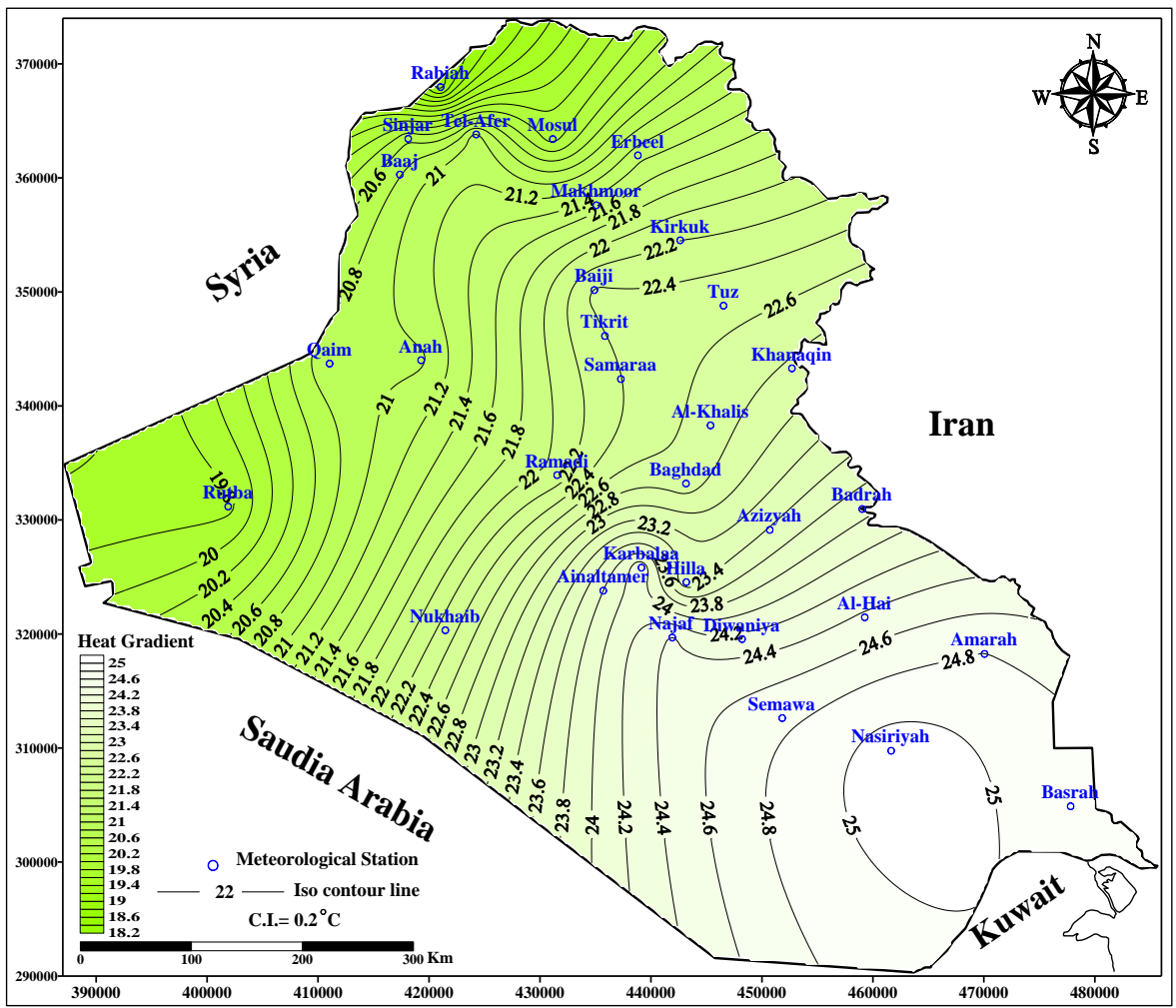

Fig. 4: Contour map of mean annual Temperature in Iraq.

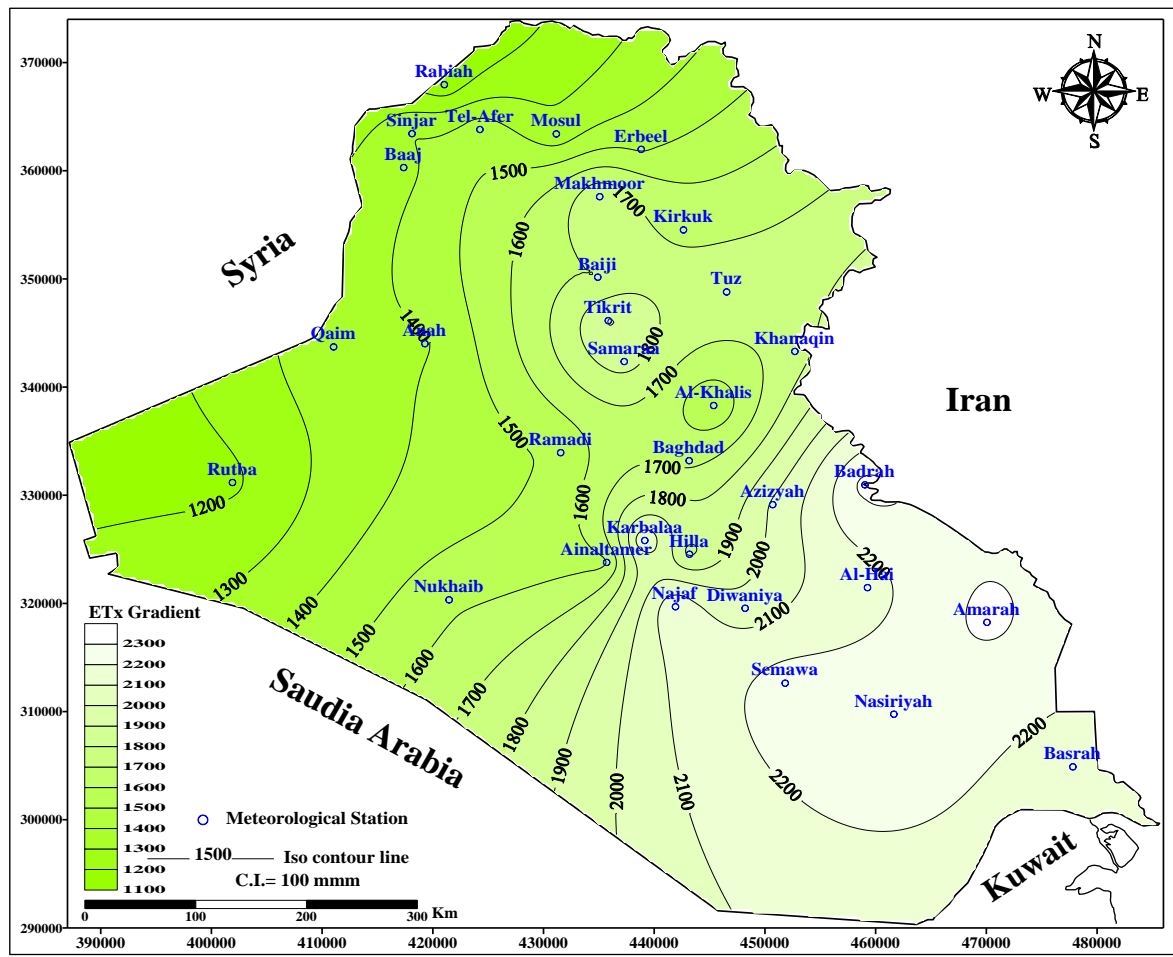

Fig. 5: Contour map of annual corrected Potential Evapotranspiration (PEc) in Iraq. 


\section{Conclusions:}

1- Thornthwaite method is one of the significant methods used to estimate the potential Evapotranspiration (PE) that is based on annual and monthly average temperature.

2- A mathematical relationship can be obtained between mean temperature with corrected potential evapotranspiration (PEc) using thornthwaite formula with (97.45) to (99.84) coefficient of determination in (7) sectors.

3- Mean temperature has a symmetrical decreasing pattern from south-east towards north-west of Iraq infected by Mediterranean Sea climate conditions, while corrected potential evapotranspiration (PEc) has the opposite direction of increasing values due to direct relationship with temperature.

\section{Conflicts of Interest}

The author declares that they have no conflicts of interest.

\section{References:}

[1] A. Subedi, and J. L. Chávez, "Crop Evapotranspiration (ET) Estimation Models: A Review and Discussion of the Applicability and Limitations of ET Methods", Journal of Agricultural Science, vol.7, no.6, 2015.

[2] H.I.Z. Al-Sudani, "Calculating of Groundwater Recharge using Meteorological Water Balance and Water level Fluctuation in Khan Al-Baghdadi Area” Iraqi Journal of Science, Vol. 59, No.1B, pp. 349359. Feb. 2018

[3] A. A. Sokolov, and T. G. Chapman, Methods for water balance computations, an international guide for research and practice. UNESCO press. Paris. 1974.

[4] S.S., Abdullah, M., Malek, A. Mustapha, and A. Aryanfar, "Hybrid of Artificial Neural NetworkGenetic Algorithm for Prediction of Reference Evapotranspiration (ET) in Arid and Semiarid Regions", Journal of Agricultural Science, Vol. 6, No.3, 191p. 2014.

[5] R.G., Allen, L.S., Pereira, D., Raes, and M. Smith, Crop evapotranspiration- Guidelines for computing crop water requirements, FAO. Rome, 1998.

[6] A. Saud, M., Azlin, M., Said, R. Abdullah and A. Hatem, "Temporal and Spatial variability of Potential Evapotranspiration in Semi-Arid Region: Case Study the Valleys of Western Region of Iraq", International Journal of Engineering Science and Technology, Vol.6, No.9, pp. 653- 660.2014.

[7] A. Henderson, The Future of the World's Climate. (Second Edition), Elsevier, Boston, 2012.

[8] C.W. Thornthwaite, . An Approach toward a Relation Classification of Climate. Geographical Review, Elsevier, Amsterdam, Vol.32, No.55, pp. 3-30. 1948

[9] H.I.Z. Al-Sudani,. Study of Morphometric properties and Water Balance using Thornthwaite method in Khanaqin Basin, East of Iraq. Journal of University of Babylon, Engineering Sciences, Vol.6, No. 3, pp.165-175. 2018.

[10] H, Vangelis, D. Tigkas and G. Tsakiris, The effect of PET method on reconnaissance drought index (RDI) calculation. Journal of Arid Environment, Vol. 88:130-140. 2013.

[11] H.K.A. AL-Shamarti, Analysis of Rainfall Seasonality Index in Iraq. Diyala Journal for pure sciences, Vol.13, No.1, pp. 188-202. 2017.

[12] L.A. Jawad, The Use of Geographic Information System Facilities to Estimate the Evapotranspiration in Iraq According to Thornthwaite Adjusted Formula. Iraqi Journal of Science, Vol.57, No.4A, pp. 2566-2574. 2016.

[13] Iraqi meteorological Organization and Seismology. Meteorological data of (32) meteorological station for different periods. Ministry of Transportation. Baghdad. Iraq. 2015. 


\section{العلاقة بين درجة الحرارة والتبخر - نتح كامن في العراق باستخدام طريقة ثورنثويت حسين العيبي زامل السوداني \\ قسم تكنولوجيا النفط، الجامعة النكنولوجية، بغداد - العراق}

dr.hussein_alsudani@yahoo.com 150098@uotechnology.edu.iq

احدى أهم النتائج في معادلة الموازنة المائية لاي منطقة طبيعية او جسم مائي هي التبخر - نتح كامن و هو أيضا عنصر مهر

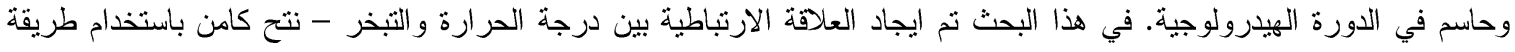
ثورنثويت في العراق من خلال تقسيم المنطقة إلى (V) قطاعات بحسب خطوط العرض الجغر افية المتندة من الجنوب الى الثشمال.

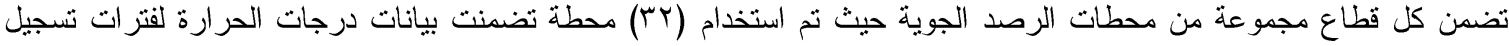
مختلفة. توصل البحث الى ايجاد علاقة رياضية بين متوسط درجة الحرارة مع معامل التبخر - نتح كامن المصحح وبمعامل ارتباط

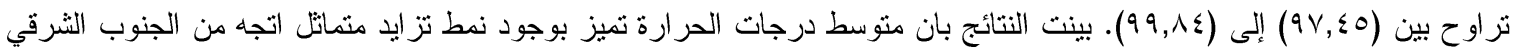

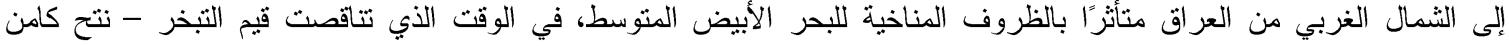

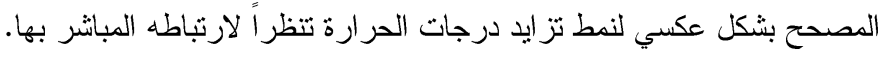
الكلمات الداله: التبخر - نتح كامن، طريقة ثورنتويت، العراق. 